\title{
Master of Science in Nursing
}

National Cancer Institute

\section{Source}

National Cancer Institute. Master of Science in Nursing. NCI Thesaurus. Code C71374.

An advanced-level quaternary education degree for Registered Nurses focusing in one or more different advanced nursing specialties. It is required to become an advanced practice nurse and is considered an entry-level degree for nurse educators and managers. It is also a prerequisite for doctorate-level nursing education. 